\title{
NEWMAN'S ERROR ANALYSIS DALAM GEOMETRI RUANG DITINJAU DARI KECERDASAN VISUAL SISWA SMA
}

\author{
Ardina Fahriyanti Maharani ${ }^{1}$, Erlina Prihatnani ${ }^{2}$ \\ ${ }^{1,2}$ Pendidikan Matematika Universitas Kristen Satya Wacana, Jalan Diponegoro No.52-60 Salatiga \\ Email penulis pertama: 202016061@student.uksw.ed
}

\begin{abstract}
In solid geometry needed the ability to visualize space that cannot be seen so differences in visual intelligence can trigger errors in solving geometry problems. Therefore, this study aimed to determine the types of errors made by students and the factors that cause errors in working on geometry problems based on Newman's Error Analysis (NEA) in terms of visual intelligence. This research chose the subjects of class XII high school who had studied the material distance points to lines in space with different levels of visual intelligence, namely high and low. The process of collecting data used visual intelligence test questions, geometry test questions, and interviews. The results of this study indicated that the level of students' visual intelligence affects the difference in location and the factor that causes errors in the stage of transformation especially on determining the distance in dimension 3. Students with high visual intelligence made mistakes at the stage of transformation and encoding that caused by the students' carelessness. However, students with low visual intelligence made mistakes at the stage of comprehension, transformation, process skills, and encoding due to the concept of the point distance to the line and the concept of the Pythagorean theorem.
\end{abstract}

Keywords: Newman's error analysis, errors, visual intelligence, distance in the solid geometry

\begin{abstract}
Abstrak
Dalam geometri ruang dibutuhkan kemampuan memvisualisasikan ruang yang tidak dapat terlihat, sehingga perbedaan kecerdasan visual dapat memicu kesalahan dalam menyelesaikan soal geometri ruang. Oleh karena itu, penelitian ini bertujuan untuk mengetahui jenis atau tipe kesalahan yang dilakukan oleh siswa dan faktorfaktor penyebab kesalahan dalam mengerjakan soal geometri ruang berdasarkan Newman's Error Analysis (NEA) ditinjau dari kecerdasan visual. Penelitian ini memilih subjek kelas XII SMA yang telah mempelajari materi jarak titik ke garis dalam ruang dengan tingkat kecerdasan visual yang berbeda, yaitu tinggi dan rendah. Proses pengumpulan data menggunakan soal tes kecerdasan visual, soal tes geometri ruang, dan wawancara. Hasil penelitian ini menunjukkan bahwa tingkat kecerdasan visual siswa mempengaruhi perbedaan letak dan faktor penyebab kesalahan dalam menyelesaikan soal menentukan jarak pada dimensi 3. Siswa dengan kecerdasan visual tinggi melakukan kesalahan pada tahap penyelesaian masalah dan penulisan kesimpulan yang disebabkan oleh kecerobohan. Namun, siswa dengan kecerdasan visual rendah melakukan kesalahan pada tahap memahami masalah, transformasi, penyelesaian masalah, serta penulisan kesimpulan dikarenakan kesalahan konsep jarak titik terhadap garis serta konsep teorema phytagoras.
\end{abstract}

Kata kunci: Newman's error analysis, kesalahan, kecerdasan visual, jarak pada geometri ruang

Salah satu bidang yang dipelajari dalam matematika adalah geometri. Geometri dibagi menjadi 2 bagian besar, yaitu geometri datar dan geometri ruang. Tertuang dalam Peraturan Menteri Pendidikan dan Kebudayaan (Permendikbud) tahun 2016 Nomor 24, geometri mulai diperkenalkan kepada siswa sejak kelas I Sekolah Dasar (SD) yang dimulai dengan pengenalan bangun ruang melalui benda konkret yang ada di sekitar dilanjutkan dengan bangun datar. Geometri terus dipelajari siswa di setiap jenjang hingga pada kelas XII SMA/MA. Salah satu KD tentang geometri di kelas XII SMA adalah menentukan jarak dalam ruang (antar titik, titik ke garis, dan titik ke bidang).

Meski geometri sudah dipelajari siswa sejak SD, namun geometri masih menjadi suatu materi yang sulit bagi siswa SMA/MA, termasuk siswa SMA/MA di Jawa Tengah. Berdasarkan data Puspendik (2018), daya serap materi geometri dan trigonometri dalam nilai UN Matematika SMA/MA IPA Tahun Pelajaran 2017/2018 masih menduduki urutan ke-3 dari 4 materi matematika yang lainnya. 
Pada setiap materi dibagi menjadi beberapa indikator, termasuk dalam geometri dan trigonometri. Geometri dan trigonometri dibagi menjadi 9 indikator yang digunakan untuk mengukur kemampuan penguasaan siswa dalam materi tersebut. Pada Tabel 1 dapat diketahui bahwa dalam geometri soal nomor urut 39 yaitu memecahkan masalah jarak pada bangun ruang memiliki persentase daya serap terendah dari indikator yang lain, dengan persentase 17,17\% di Jawa Tengah dan 11,95\% secara nasional.

\section{Tabel 1}

Daya Serap Indikator Materi Geometri dan Trigonometri UN SMA/MA IPA Tahun 2017/2018

\begin{tabular}{|c|l|c|c|}
\hline $\begin{array}{c}\text { No. } \\
\text { Urut }\end{array}$ & \multicolumn{1}{|c|}{ Indikator yang Diuji } & Provinsi & $\begin{array}{c}\text { Nasiona } \\
\text { I }\end{array}$ \\
\hline Geometri dan Trigonmetri & 41,52 & 35,67 \\
\hline 22 & $\begin{array}{l}\text { Menentukan nilai perbandingan trigonometri yang lain pada suatu } \\
\text { segitiga siku-siku }\end{array}$ & 48,14 & 39,58 \\
\hline 23 & $\begin{array}{l}\text { Memcahkan masalah menggunakan perbandingan trigonometri pada } \\
\text { permasalahan sehari-hari }\end{array}$ & 61,30 & 51,96 \\
\hline 24 & $\begin{array}{l}\text { Menentukan luas segitiga sembarang dengan diketahui sudut apit dan } \\
\text { dua sisi yang mengapitnya }\end{array}$ & 34,94 & 27,07 \\
\hline 25 & Memecahkan permasalahn jarak pada bangun ruang & 31,42 & 29,72 \\
\hline 26 & $\begin{array}{l}\text { Menentukan sudut antara dua garis yang bersilangan pada sebuah } \\
\text { bangun ruang }\end{array}$ & 45,39 & 40,11 \\
\hline 27 & $\begin{array}{l}\text { Menentukan persamaan lingkaran yang diketahui pusat dan salah satu } \\
\text { titik yang dilalui }\end{array}$ & 40,70 & 33,45 \\
\hline 28 & Menentukan pers garis singgung lingkaran yang berpusat di (p,q) & 17,17 & 11,95 \\
\hline 29 & Memecahkan masalah dengan menggunakan perbandingan trigonometri \\
\hline 39 & Memecahkan masalah jarak pada bangun ruang & 34,09 & 33,05 \\
\hline
\end{tabular}

Sumber: http://puspendik.kemdikbud.go.id/hasil-un/

Rendahnya daya serap pada indikator memecahkan masalah jarak pada bangun ruang menunjukkan terdapat kesalahan-kesalahan siswa SMA/MA dalam menyelesaikan soal terkait materi tersebut. Oleh karena itu, perlu adanya suatu kajian yang dapat digunakan untuk mengetahui letak kesalahan-kesalahan yang mungkin dilakukan siswa pada soal jarak pada bangun ruang. Suatu kajian yang dapat digunakan untuk mengganalisis letak kesalahan-kesalahan yang mungkin dilakukan siswa yaitu analisis kesalahan.

Analisis kesalahan menurut Peteda (1989) adalah suatu teknik untuk mengidentifikasi, mengklarifikasikan, dan menginterpretasikan secara sistematis kesalahan-kesalahan yang dilakukan siswa. Menurut Ketterline dan Yofanof (Isran, 2017) mengatakan bahwa analisis kesalahan adalah langkah untuk mengidentifikasi pola-pola ketidakmengertian siswa yang dapat dilihat pada jawaban siswa. Salah satu metode yang dapat digunakan untuk mengidentifikasi kesalahan siswa yaitu analisis kesalahan menurut Newman atau Newman's Error Analysis (NEA). Menurut Prakitipong dan Nakamura (2016), The Newman Procedure is a method that analyzes errors in sentence problems, artinya NEA merupakan sebuah metode yang dapat digunakan untuk menganalisis kesalahan pada soal uraian. 
Newman's Error Analysis Dalam Geometri Ruang Ditinjau Dari Kecerdasan Visual Siswa SMA, Ardina Fahriyanti Maharani, Erlina Prihatnani

Menurut Newman (White, 2010), saat seseorang mengerjakan soal matematika maka orang tersebut sudah melewati 5 tahap yaitu: (1) reading (membaca soal); (2) comprehension (memahami soal); (3) transformation (transformasi); (4) process skills (proses penyelesaian); (5) encoding (penulisan kesimpulan). Newman (Singh Parmjit, Arba Abdul Rahman, \& Teoh Sian Hoon, 2010) juga mengatakan bahwa terdapat 5 jenis kesalahan yang dapat diketahui dengan prosedur NEA. Indikator kesalahan masing-masing tahap menurut NEA yang digunakan dalam penelitian ini dapat dilihat pada Tabel 2.

Tabel 2

Indikator Kesalahan Siswa dalam Mengerjakan Soal Geometri Ruang Kelas XII SMA KD 4.1 "Jarak Titik ke Garis"

\begin{tabular}{|c|c|}
\hline $\begin{array}{c}\text { Jenis } \\
\text { Kesalahan }\end{array}$ & Indikator Kesalahan \\
\hline Membaca & $\begin{array}{l}\text { a. Siswa melakukan kesalahan dalam membaca kata-kata, simbol, atau informasi } \\
\text { penting yang terdapat pada soal. }\end{array}$ \\
\hline $\begin{array}{ll}\mathrm{M} \\
\mathrm{ma}\end{array}$ & $\begin{array}{l}\text { a. Siswa melakukan kesalahan dalam menyatakan kembali maksud soal dengan } \\
\text { bahasanya sendiri. } \\
\text { b. Siswa melakukan kesalahan dalam menyebutkan hal-hal yang terdapat pada } \\
\text { soal. } \\
\text { c. Siswa melakukan kesalahan dalam menunjukkan suatu makna atau istilah yang } \\
\text { terdapat pada soal. }\end{array}$ \\
\hline Trans & $\begin{array}{l}\text { a. Siswa melakukan kesalahan dalam menggambar bangun ruang sesuai dengan } \\
\text { jenis bangun ruang yang disebutkan pada soal. Misalnya, dalam soal diketahui } \\
\text { limas namun menggambar prisma. } \\
\text { b. Siswa melakukan kesalahan dalam memberikan nama unsur-unsur bangun } \\
\text { ruang (misal dalam memberi nama titik atau garis). } \\
\text { c. Siswa melakukan kesalahan dalam meletakkan panjang suatu garis yang } \\
\text { dimaksud dalam soal. } \\
\text { d. Siswa melakukan kesalahan dalam menunjukkan secara benar informasi dari } \\
\text { soal. Misalnya, pada soal dituliskan rusuk tegak limas namun siswa } \\
\text { menunjukkan tinggi limas. } \\
\text { e. Siswa melakukan kesalahan dalam merepresentasikan suatu daerah pada bangun } \\
\text { ruang kedalam bentuk bangun datar. }\end{array}$ \\
\hline $\begin{array}{l}\text { Proses } \\
\text { penyelesaian } \\
\text { masalah }\end{array}$ & $\begin{array}{l}\text { a. Siswa melakukan kesalahan dalam penulisan rumus yang digunakan untuk } \\
\text { menyelesaikan soal yang diberikan. } \\
\text { b. Siswa melakukan kesalahan dalam tahap komputasi atau perhitungan. }\end{array}$ \\
\hline $\begin{array}{l}\text { Penulisan } \\
\text { kesimpulan }\end{array}$ & $\begin{array}{l}\text { a. Siswa melakukan kesalahan dalam menuliskan hasil akhir dari soal yang } \\
\text { berikan. } \\
\text { b. Siswa melakukan kesalahan dalam menuliskan besaran satuan yang terdapat } \\
\text { dalam soal pada hasil akhir. } \\
\text { c. Siswa melakukan kesalahan dengan tidak menuliskan besaran satuan yang } \\
\text { terdapat dalam soal pada hasil akhir. } \\
\text { d. Siswa melakukan kesalahan dengan tidak menuliskan kesimpulan jawaban dari } \\
\text { soal yang diberikan. }\end{array}$ \\
\hline
\end{tabular}

Lima tahapan tersebut juga diperlukan dalam menyelesaikan soal tentang jarak pada bangun ruang. Oleh karena itu, dalam mengkaji kemungkinan-kemungkinan kesalahan yang dapat dilakukan siswa dalam menyelesaikan soal jarak pada dimensi 3 dapat dikaji berdasarkan lima tahapan dalam 
NEA.

Dalam menyelesaikan soal jarak dalam ruang seperti ini dibutuhkan kemampuan siswa untuk dapat memvisualisasikan ruang yang tidak dapat dilihat. Kemampuan tersebut dikenal dengan kecerdasan spasial.

Gardner (2003) menyatakan bahwa kecerdasan spasial atau yang dikenal juga sebagai kecerdasan visual atau kecerdasan ruang adalah kemampuan membentuk model mental dari dunia ruang dan mampu melakukan berbagai tindakan dan operasi menggunakan model itu. Selain itu, Yaumi (2012) menyatakan bahwa kecerdasan visual dapat didefinisikan sebagai kemampuan untuk memahami gambar-gambar dan bentuk termasuk kemampuan untuk menginterpretasi dimensi ruang yang tidak dapat dilihat. Menurut Sonawat dan Gogri (Yaumi, 2012), kemampuan visual merupakan kemampuan berpikir dalam bentuk visualisasi, gambaran, serta bentuk tiga dimensi. Berdasarkan ketiga pengertian kecerdasan visual, maka dapat disimpulkan bahwa kecerdasan visual merupakan kemampuan untuk menginterpretasikan dan membentuk model mental dari dimensi ruang serta kemampuan untuk melakukan berbagai tindakan dan operrasi menggunakan model tersebut.

Menurut Maier (Prihatnani, 2016), terdapat lima komponen kecerdasan visual yaitu spatial perception, visualization, mental rotation, spatial relations, dan spatial orientation. Pada Tabel 3 disajikan indikator dari setiap komponen kecerdasan visual yang digunakan dalam penelitian ini.

\section{Tabel 3}

\section{Indikator Kecerdasan Visual}

\begin{tabular}{|l|l|}
\hline \multicolumn{1}{|c|}{ Komponen } & \multicolumn{1}{c|}{ Indikator Komponen } \\
\hline $\begin{array}{l}\text { Spatial } \\
\text { Perception }\end{array}$ & $\begin{array}{l}\text { kemampuan menentukan arah vertikal dan horizontal dari suatu objek yang keberadaan } \\
\text { posisinya dikacaukan misal, benda tersebut dimiringkan ke kanan atau ke kiri }\end{array}$ \\
\hline Visualization & $\begin{array}{l}\text { kemampuan untuk memvisualisasikan/ melihat sebuah konfigurasi di mana terdapat } \\
\text { gerakan atau perpindahan pada bagian dari konfigurasi tersebut }\end{array}$ \\
\hline $\begin{array}{l}\text { Mental } \\
\text { rotation }\end{array}$ & $\begin{array}{l}\text { kemampuan secara cepat dan akurat dalam menentukan hasil dari suatu rotasi dari } \\
\text { gambar 2 dimensi atau pun 3 dimensi }\end{array}$ \\
\hline $\begin{array}{l}\text { Spastial } \\
\text { relation }\end{array}$ & $\begin{array}{l}\text { kemampuan untuk mengenali konfigurasi spasial dari objek atau bagian dari objek serta } \\
\text { kaitan antara satu dengan yang lain }\end{array}$ \\
\hline $\begin{array}{l}\text { Spatial } \\
\text { orientation }\end{array}$ & $\begin{array}{l}\text { kemampuan untuk masuk ke dalam situasi spasial tertentu, contohnya, menebak hasil } \\
\text { foto suatu benda yang difoto dari sudut tertentu }\end{array}$ \\
\hline
\end{tabular}

Namun, tidak semua siswa memiliki kecerdasan visual yang sama. Gardner (2003) menyatakan

bahwa tidak semua orang mempunyai minat dan kemampuan yang sama, termasuk kecerdasan visual setiap orang. Dengan adanya perbedaan tingkat kecerdasan visual yang dimiliki siswa, berarti dimungkinkan terdapat perbedaan kemampuan siswa untuk menginterpretasikan atau memvisualisasikan ruang atau bangun ruang. Hal ini dapat berdampak pada bervariasinya kesalahankesalahan yang dialami siswa dalam menyelesaikan soal geometri.

Beberapa penelitian telah menggunakan analisis kesalahan, NEA, atau kecerdasan visual, seperti penelitian Farida (2015) tentang analisis kesalahan siswa dalam menyelesaikan soal cerita mateamtika serta penelitian Mulyadi, Riyadi, \& Sri Subanti (2105). Mulyadi dkk (2015) melakukan penelitian terhadap siswa SMP N 2 Kebonagung Kabupaten Pacitan yang menyimpulkan bahwa dalam 
Newman's Error Analysis Dalam Geometri Ruang Ditinjau Dari Kecerdasan Visual Siswa SMA, Ardina Fahriyanti

menyelesaikan soal tentang luas permukaan bangun ruang terdapat perbedaan kesalahan yang dilakukan antara subjek dengan tingkat kecerdasan visual yang berbeda. Subjek dengan kecerdasan visual tinggi dan sedang melakukan kesalahan transformasi dan kesimpulan, sedangkan subjek kecerdasan visual rendah mengalami kesalahan pemhaman, transformasi, penyelesaian, serta penarikan kesimpulan. seperti halnya dengan penelitian tersebut, maka dalam penelitian ini akan menganalisis kesalahan siswa dalam menyelesaikan soal tentang jarak dalam ruang dengan menggambil subjek dengan tingkat kecerdasan visual yang berbeda.

Dari hasil penelitian Mulyadi dkk (2015) juga dapat diketahui bahwa kesalahan yang dilakukan subjek dengan kecerdasan visual tinggi berbeda dengan subjek dengan kecerdasan visual rendah. Oleh karena itu, penelitian ini akan membahas kesalahan pada subjek yang memiliki kecerdasan visual tinggi dan rendah. Dengan cara pengambilan subjek yang seperti demikian diharapkan dapat memberikan gambaran letak dan faktor penyebab kesalahan-kesalahan siswa yang memiliki kecerdasan visual yang berbeda. hasil penelitian ini diharapkan dapat dijadikan dasar bagi guru sebagai bahan refleksi dalam menerapkan pembelajaran pada dimensi 3. Dengan begitu, diharapkan daya serap siswa kelas XII terhadap materi geometri dapat lebih baik.

\section{METODE}

Penelitian ini merupakan peneltian kualitatif. Subjek yang digunakan dalam penelitian ini adalah siswa kelas XII SMA Tahun 2017/2018 dengan tingkat kecerdasan visual yang berbeda yaitu tinggi dan rendah. Subjek dipilih adalah siswa kelas XII dengan kriteria: (1) telah mempelajari materi jarak titik ke garis dalam ruang, (2) memiliki kemampuan visual tergolong tinggi atau rendah.

Pengumpulan data menggunakan soal tes kecerdasan visual, soal tes geometri ruang, pedoman indikator kesalahan Newman, serta wawancara. Instrumen tes kecerdasan visual terdiri dari 20 soal, soal disusun berdasarkan 5 indikator kecerdasan visual menurut Maier dengan jumlah 4 soal per komponen indikator.

Selain itu, pada instrumen tes geometri ruang ini terdiri dari 2 soal uraian yang disusun berdasarkan KD 4.1 matematika wajib kelas XII yang dikhususkan pada sub bab jarak titik ke garis. Dalam mengidentifikasi kesalahan yang dilakukan subjek, pada penelitian ini menggunakan indikator kesalahan menurut Newman yang telah disesuaikan berdasarkan topik yang digunakan yaitu jarak titik ke garis (Tabel 2).

\section{HASIL}

\section{Hasil Analisis Pada Subjek Visual Tinggi (VT)}

Berdasarkan analisis hasil tes dan wawancara diketahui bahwa VT tidak melakukan kesalahan pada tahap membaca untuk semua soal yang berikan. Hal ini dibuktikan dari kebenaran subjek dalam membaca setiap kata, simbol, atau informasi penting yang terdapat dalam setiap soal. 
Pada tahap memahami soal, VT dapat menyebutkan informasi-informasi yang terdapat pada soal serta dapat menjelaskan kedua soal dengan kalimatnya sendiri. Hal-hal yang disebutkan oleh subjek terkait hal yang diketahui dan yang ditanyakan untuk soal nomor 1 dapat dilihat dari kutipan wawancara berikut.

P : :Yang diketahui dari soal nomor 1 apa aja?"

VT : "Diketahui panjang rusuknya $8 \mathrm{~cm} . "$

$\mathrm{P} \quad$ : "Panjang rusuk dari apa?"

VT : "Panjang rusuk kubus ABCD.EFGH"

$\mathrm{P} \quad$ : "Ada kubus yang panjang rusuknya $8 \mathrm{~cm}$. Oke. Yang ditanyakan?”

VT : "Jarak dari titik E ke garis BD."

Adapun untuk nomor 2, subjek mampu menyebutkan "Diketahui limas beraturan T.ABCD. terus diketahui panjang AB nya $3 \mathrm{~cm}$, TA $6 \mathrm{~cm}$ " sebagai hal yang diketahui dan "Jarak dari titik B ke rusuk TD” sebagai hal yang ditanyakan. Selain itu, subjek mampu menunjukkan suatu makna atau istilah yang terdapat dalam soal. Contohnya pada soal nomor 1, subjek dapat menunjukkan jarak dari titik E ke garis BD adalah garis EI (Gambar 1). Adapun untuk soal nomor 2, subjek mampu menunjukkan bahwa jarak titik B ke garis TD adalah garis baru yang digambarkan subjek dari titik B ke suatu titik pada rusuk TD (Gambar 2). Ketepatan subjek dalam menyebutkan hal yang diketahui, hal yang ditanyakan, serta kemampuan memaknai istilah yang terdapat dalam kedua soal menunjukkan bahwa subjek mampu memahami semua soal yang diberikan.

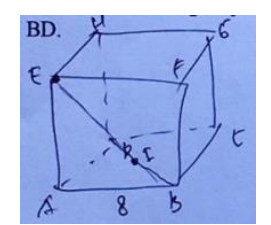

Gambar 1. Gambar Kubus Oleh Subjek VT

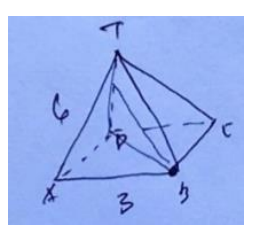

Gambar 2. Gambar Limas Beraturan Oleh Subjek VT

Pada tahap transformasi, subjek mampu menggambarkan bangun ruang yang disebutkan pada soal dengan menggambarkan bangun kubus ABCD.EFGH serta limas beraturan T.ABCD dengan proporsi yang sesuai, sehingga dapat terlihat sebagai kubus dan limas segi empat beraturan meskipun digambar tanpa menggunakan alat bantu penggaris. Bangun ruang yang digambarkan subjek dapat dilihat pada Gambar 1 dan Gambar 2. Dari kedua gambar tersebut juga dapat diketahui bahwa VT dapat memberikan penamaan sudut sesuai dengan keterangan yang terdapat dalam soal. Selain itu, subjek mampu meletakkan informasi panjang rusuk-rusuk yang dimaksud dalam soal dengan memberikan keterangan pada gambar bangun yang dibuat. Tidak hanya itu, VT juga mampu merepresentasikan suatu daerah dimensi 3 ke dalam dimensi 2 dengan benar. Hal ini dapat dilihat dari bagaimana subjek menggambarkan garis EI sebagai perwujudan jarak E terhadap garis BD pada kubus ABCD.EFGH ke dalam gambar bangun datar segitiga BDE (Gambar 3). Kemampuan yang sama juga ditunjukkan subjek VT pada soal nomor 2. Subjek dapat merepresentasikan garis BI dan TD ke dalam sebuah bidang datar 
Newman's Error Analysis Dalam Geometri Ruang Ditinjau Dari Kecerdasan Visual Siswa SMA, Ardina Fahriyanti

yaitu segitiga BDT (Gambar 4). Subjek mengatakan bahwa cara yang subjek gunakan untuk mentransformasikan ke dalam bentuk dimensi 2 yaitu dengan menghubungkan unsur-unsur yang ditanyakan dalam soal. Contohnya untuk soal nomor 1, ditanyakan jarak titik E ke garis BD, sehingga subjek menggambarkan segitiga BDE dimana dalam segitiga tersebut memuat unsur titik E dan garis BD. Selanjutnya, subjek dapat menjelaskan bahwa prinsip jarak titik ke garis merupakan panjang garis yang terbentuk melewati titik tersebut dan tegak lurus terhadap garis yang ditanyakan. Misalnya untuk soal nomor 1, jarak titik B ke garis BD merupakan panjang garis yang melalui B dan tegak lurus garis BD. Demikian juga pada soal nomor 2, subjek menjelaskan bahwa jarak titik B ke TD merupakan panjang garis yang tegak lurus dari titik B terhadap rusuk TD. Dengan begitu, meskipun subjek VT tidak memberikan tanda tegak lurus pada perpotongan garis EI dengan BD pada Gambar 3 dan perpotongan garis BI dengan TD pada Gambar 4, tetapi subjek mengetahui bahwa kedua pasang garis tersebut masing-masing saling tegak lurus. Berikut adalah kutipan wawancara yang menyatakan bahwa subjek mengetahui hubungan kedua garis tersebut adalah tegak lurus.

(Untuk Soal Nomor 1)

$\mathrm{P} \quad$ : “Terus itu kan kamu tarik garis dari E ke garis BD. Itu karena apa?”

VT :“ Karena itu tadi, untuk cari jarak E ke BD kan cari yang tegak lurus. Terus kita kenapa tarik dari E ke titik lain misalnya misal titik I. Nah tarikan itu adalah jarak titik E ke BD, karena tegak lurus dari titik E ke garis BD nya."

(Untuk Soal Nomor 2)

VT : “..., yang ditanya kan jarak titik B ke TD. Kalau jarak B ke TD kan sama aja kita mencari yang tegak lurus dari titik B ke rusuk TD."

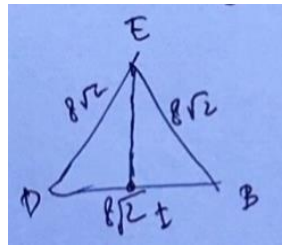

Gambar 3. Representasi Titik E dan Garis BD di Bidang BDE Oleh Subjek VT

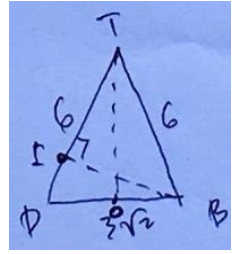

Gambar 4. Representasi Titik B dan Garis TD di Bidang BTD Oleh Subjek VT

Berdasarkan uraian tersebut, diketahui bahwa subjek VT mampu menggambarkan bangun ruang yang disebutkan dalam soal, memberikan penamaan sudut, meletakkan panjang rusuk, serta mampu mempresentasikan kedudukan titik dan garis ke dalam bentuk bangun datar dengan benar. Oleh karena itu dapat disimpulkan bahwa subjek tidak melakukan kesalahan pada tahap transformasi.

Tahap selanjutnya adalah proses penyelesaian masalah. Hasil pekerjaan subjek pada tahap ini untuk soal nomor 1 dan nomor 2 secara berturut-turut dapat dilihat pada Gambar 5 dan Gambar 6. Pada tahap ini, subjek tidak melakukan kesalahan dalam memilih maupun menuliskan rumus yang digunakan. Subjek menyelesaikan soal nomor 1 (menentukan panjang garis EI) dengan menggunakan rumus phytagoras, sedangkan untuk soal nomor 2, subjek menggunakan rumus kesamaan luas segitiga 
untuk menghitung panjang garis BI. Selain itu, subjek juga mampu menjelaskan setiap langkah penyelesaian masalah yang dilakukannya. Contohnya pada soal nomor 1, subjek menghitung panjang EI dengan mensubstitusikan panjang garis BE dan BI ke dalam rumus phytagoras, dimana panjang BI adalah setengah dari panjang BD. Pada saat wawancara, subjek mengatakan hal itu terjadi dikarenakan segitiga BDE merupakan segitiga sama sisi, sehingga menyebabkan garis EI memotong BD menjadi dua bagian yang sama panjang.

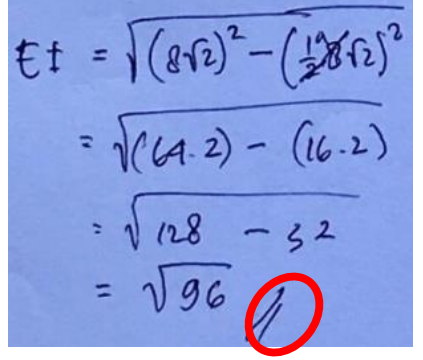

Gambar 5. Proses Penyelesaian Masalah Subjek VT Soal Nomor 1

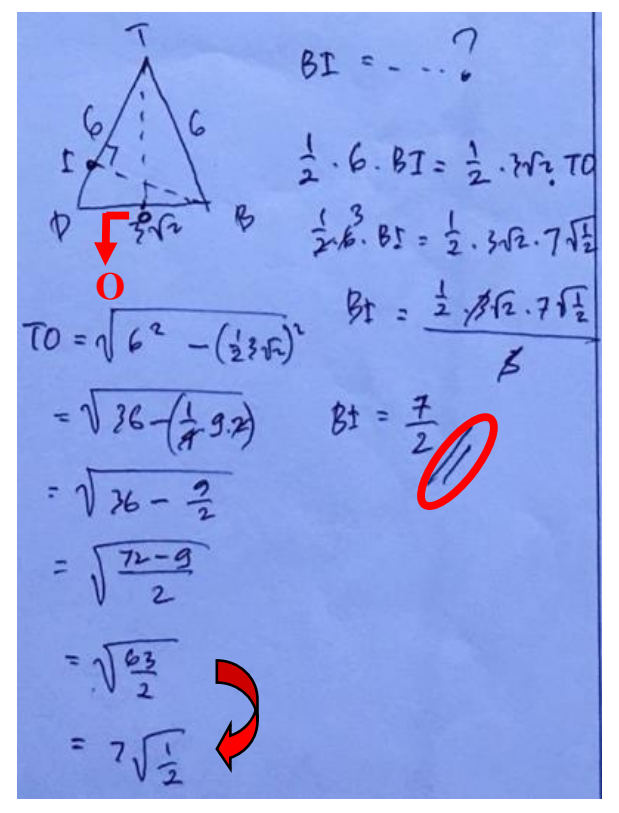

Gambar 6. Proses Penyelesaian Masalah Subjek VT Soal Nomor 2

Meskipun tidak ada kesalahan dalam memilih rumus serta mensubstitusikan yang diketahui dalam rumus tersebut, namun dalam melakukan komputasi atau perhitungan, subjek melakukan kesalahan dalam menentukan panjang TO pada soal nomor 2. Hal ini tampak pada Gambar 6, subjek salah dalam menyederhanakan $\sqrt{\frac{63}{2}}$ menjadi $7 \sqrt{\frac{1}{2}}$. Subjek menanggap bahwa $7^{2}$ hasilnya adalah 63 . Kesalahan ini disadari subjek dengan merevisi sendiri jawabannya pada saat wawancara, sehingga dapat disimpulkan bahwa faktor penyebab kesalahan ini adalah kecerobohan yang dilakukan subjek dalam melakukan perhitungan penyederhanaan bentuk akar.

Berdasarkan uraian tersebut dapat disimpulkan bahwa pada tahap proses penyelesaian masalah, subjek VT tidak melakukan kesalahan dalam menentukan dan menuliskan rumus yang digunakan untuk menyelesaikan semua soal, namun subjek melakukan kesalahan komputasi yang diakibatkan faktor

\section{kecerobohan.}

Pada tahap penulisan kesimpulan, subjek melakukan kesalahan penulisan hasil akhir untuk soal nomor 2. Hal ini dikarenakan kesalahan komputasi pada tahap proses penyelesaiaan masalah. Dalam memberikan kesimpulan jawaban, secara konsisten subjek menggunakan tanda dua garis miring di bawah hasil perhitungannya untuk menunjukkan hasil akhir kedua soal yang diberikan. Meskipun 
Newman's Error Analysis Dalam Geometri Ruang Ditinjau Dari Kecerdasan Visual Siswa SMA, Ardina Fahriyanti

subjek mengetahui bahwa besaran satuan panjang dari hasil perhitungan kedua soal tersebut adalah $\mathrm{cm}$, akan tetapi di setiap jawaban subjek, subjek tidak menuliskan satuan panjang tersebut. Dari uraian tersebut, dapat disimpulkan bahwa subjek VT pada tahap ini melakukan kesalahan dalam tahap kesimpulan yaitu tidak mencantumkan satuan panjang pada setiap jawaban akhir serta memberikan hasil akhir jawaban yang tidak benar yang disebabkan kesalahan komputasi pada tahap sebelumnya.

\section{Hasil Analisis Pada Subjek Visual Rendah (VR)}

Berikut ini adalah hasil analisis kesalahan subjek VR dalam mengerjakan soal dimensi tiga berdasarkan hasil tes serta wawancara. Pada tahapan pertama yaitu tahap membaca, sama seperti subjek VT, subjek VR tidak melakukan kesalahan membaca untuk semua soal yang diberikan. Hal ini dibuktikan dari subjek VR benar dalam membaca setiap kata, simbol, atau informasi yang terdapat pada kedua soal yang diberikan.

Selanjutnya pada tahap memahami masalah, subjek VR dapat menyebutkan hal yang diketahui dan hal yang ditanyakan dari kedua soal yang diberikan. Pada soal nomor 1, subjek mampu menyebutkan hal yang diketahui dari soal tersebut yaitu panjang rusuk kubus ABCD.EFGH serta yang ditanyakan adalah jarak titik E ke rusuk BD. Begitu juga untuk soal nomor 2, subjek mampu menyebutkan informasi yang diperoleh dari soal tersebut. Hal ini dapat dilihat dari kutipan wawancara berikut.

$\mathrm{P} \quad$ : "Dari soal nomor 2, hal yang diketahui dan yang ditanyakan itu apa?"

VR :"Diketahui panjang rusuk AB, sama panjang rusuk TA. Terus ditanyain jarak titik B ke $T D^{\prime \prime}$

$\mathrm{P} \quad$ : "AB dan TA itu bagian dari apa?"

VR : "Rusuk dari limas segi empat beraturan"

Namun demikian, subjek salah dalam memaknai jarak titik B ke garis TD. Subjek menganggap bahwa jarak titik B terhadap garis TD merupakan panjang garis yang ditarik dari titik B dan yang membagi garis TD menjadi 2 bagian yang sama besar. Hal ini dapat dilihat dari kutipan wawancara berikut.

$\mathrm{P} \quad$ : “..., definisi jarak dari titik E ke garis BD itu apa?”

VR : “Tengah-tengah ini (menunjuk garis BD) ke E"

Kesalahan yang sama juga dilakukan subjek untuk soal nomor 2. Hal tersebut menunjukkan bahwa subjek tidak mengetahui konsep jarak suatu titik A terhadap garis $g$ sebagai panjang ruas garis yang ditarik dari titik A dan tegak lurus garis $g$. Berdasarkan uraian tersebut, dapat disimpulkan bahwa pada tahap memahami masalah, subjek VR tidak melakukan kesalahan dalam menyebutkan hal yang diketahui dan hal yang ditanyakan untuk semua soal yang diberikan, namun subjek salah dalam mendefinisikan suatu makna yang terdapat pada soal yaitu makna jarak titik ke garis. Kesalahan ini dikarenakan kesalahan konsep subjek dalam memahami konsep menentukan jarak titik ke garis. 
Pada tahap transformasi, subjek VR mampu menggambarkan bangun ruang lengkap dengan penamaan sudut dan memberikan keterangan panjang rusuk sesuai dengan soal yang diberikan. Hal ini dapat dilihat dari sketsa subjek pada Gambar 7 untuk soal nomor 1 serta Gambar 8 untuk soal nomor 2. Namun demikian untuk menggambarkan alas limas pada Gambar 8, subjek tidak menggunakan prinsip gambar perspektif sehingga alas digambar benar-benar dalam bentuk persegi.

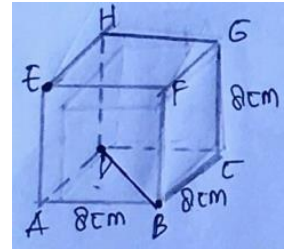

Gambar 7. Gambar Kubus Oleh Subjek VR

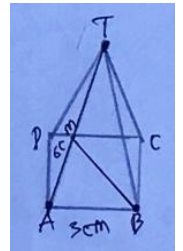

Gambar 8. Gambar Limas Beraturan Oleh Subjek VR

Dalam mentransformasikan hal yang ditanyakan, pada soal nomor 1 subjek tidak menggambarkan garis yang mewakili jarak titik E terhadap garis BD ke dalam kubus ABCD.EFGH, namun langsung menggambarkannya ke dalam bentuk dimensi 2 yaitu pada bangun segitiga BDE (Gambar 9). Adapun untuk soal nomor 2, subjek mentransformasikan baik dalam limas segi empat (Gambar 8) maupun dalam bentuk bangun datar segitiga (Gambar 10). Meskipun demikian, pada soal nomor 2, subjek salah merepresentasikan yang ditanyakan pada soal yaitu jarak B terhadap TD, namun subjek mentransformasikan terhadap TA. Kesalahan ini dikarenakan kecerobohan yang dilakukan subjek, hal ini dibuktikan pada saat wawancara subjek mengatakan bahwa seharusnya pada Gambar 10 merupakan segitiga TBD bukan segitiga TAB. Selain itu, untuk kedua soal yang diberikan, subjek juga salah dalam mentransformasikan jarak titik ke garis dengan menjadikan garis baru yang melalui suatu titik yang membagi garis di depannya menjadi 2 bagian sama panjang. Hal ini dikarenakan kesalahan konsep yang dipahami subjek.

Berdasarkan uraian tersebut dapat disimpulkan bahwa dalam tahap transformasi, subjek VR tidak dapat melakukan transformasi dengan benar dari hal yang ditanyakan. Hal ini dikarenakan kesalahan kecerobohan dalam melihat unsur bangun ruang serta kesalahan konsep jarak titik ke garis yang dipahami oleh subjek.

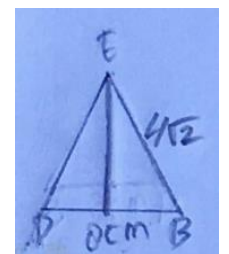

Gambar 9. Representasi jarak pada soal nomor 1 oleh subjek VR

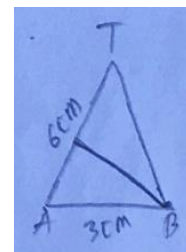

Gambar 10. Representasi jarak pada soal nomor 2 oleh subjek VR 
Newman's Error Analysis Dalam Geometri Ruang Ditinjau Dari Kecerdasan Visual Siswa SMA, Ardina Fahriyanti

Pada tahap penyelesaian masalah, subjek tidak mengetahui rumus apa yang harus digunakan untuk menyelesaikan semua soal yang diberikan. Hal ini dilihat dari subjek yang memilih rumus yang diingatnya. Subjek mengatakan, "Cuma setauku untuk cari kayak gini (jarak titik ke garis) itu pasti ada akarnya, terus nanti ada ini (setengah alas) dikadratkan dan sisi samping (sisi miring) dikuadratkan". Subjek juga tidak mengetahui prinsip phytagoras. Hal tersebut dapat dilihat dari kutipan wawancara berikut.

P : "Cara cari panjang BE itu gimana?"

VR : "Setengah rusuknya (kubus) dikali $\sqrt{2}$ "

$\mathrm{P} \quad:$ " $\sqrt{2}$ karna apa?”

VR : "Kubus"

Subjek juga tampak hanya menggunakan rumus yang dihafalkan untuk menentukan panjang BE. Tak hanya itu, ketidaktahuan subjek mengenai prinsip phyatgoras juga nampak dari soal nomor 1 dalam menentukan jarak E ke BD (Gambar 11) serta dalam menentukan jarak B ke TD pada soal nomor 2 (Gambar 12). Dari kedua gambar tersebut nampak bahwa untuk mencari panjang salah satu sisi yang mengapit sudut siku-siku dengan cara menjumlahkan kuadrat sisi miring dengan kuadrat sisi siku-siku yang lain, dari yang seharusnya pengurangan dari kuadrat sisi miring dengan sisi siku-siku yang lain. Pada tahap ini, subjek juga tidak dapat menghubungkan representasi jarak titik terhadap garis pada dimensi 3 dan pada dimensi 2. Seperti pada soal nomor 1, subjek tidak mampu menentukan panjang DE yang seharusnya sama dengan panjang BE. Hal ini disebabkan ketidakmampuan subjek dalam melihat garis DE dalam kubus ABCD.EFGH sebagai diagonal sisi.

Meskipun demikian, dilihat dari Gambar 11 dan Gambar 12 dapat diperoleh informasi bahwa subjek VR tidak melakukan kesalahan dalam perhitungan. Subjek mampu menghitung hasil suatu penjumlahan, perkalian, kuadrat, dan penyederhanaan bentuk akar dengan benar. Berdasarkan hal tersebut dapat disimpulkan subjek melakukan kesalahan dalam menyelesaikan masalah pada setiap soal yang diberikan dikarenakan ketidakmampuan subjek dalam menentukan langkah yang harus digunakan serta ketidakmampuan subjek mengenai prinsip phytagoras.

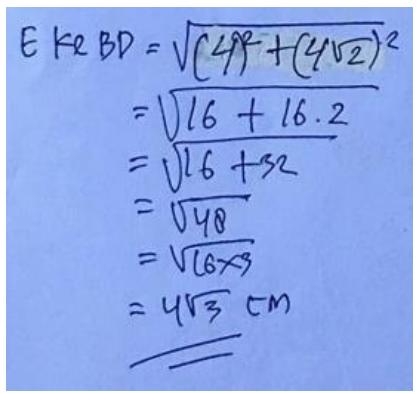

Gambar 11. Proses Penyelesaian Masalah Subjek VR Soal Nomor 1

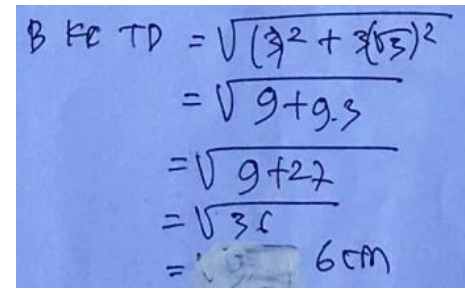

Gambar 12. Proses Penyelesaian Masalah Subjek VR Soal Nomor 2 
Pada tahap terakhir yaitu penulisan kesimpulan, berdasarkan jawaban subjek yang dapat dilihat pada Gambar 11 dan Gambar 12, terlihat bahwa subjek telah menuliskan satuan dari setiap hasil akhir semua soal yang diberikan. Meskipun demikian, subjek tidak dapat menuliskan jawaban akhir yang benar dikarenakan kesalahan subjek pada tahap proses penyelesaian masalah. Berdasarkan uraian tersebut dapat disimpulkan bahwa pada tahap penulisan kesimpulan, subjek VR melakukan kesalahan yaitu tidak dapat menuliskan hasil akhir dengan benar untuk semua soal yang diberikan dikarenakan kesalahan pada tahap penyelesaian masalah.

\section{Pembahasan}

Berdasarkan hasil analisis dan wawancara dapat diketahui bahwa subjek dengan tingkat kecerdasan visual berbeda tidak melakukan kesalahan membaca. Tidak hanya pada penelitian ini, kebenaran subjek pada tahap membaca juga berlaku pada peneltian lainnya, seperti Farida (2015) dan Mulyadi dkk (2015) yang menyimpulkan bahwa subjek pada peneltian tersebut tidak melakukan kesalahan pada tahap membaca.

Namun demikian pada penelitian ini terdapat perbedaan letak kesalahan serta faktor penyebab kesalahan yang dilakukan kedua subjek di tahap lainnya. Pada tahap memahami soal, subjek kecerdasan visual tinggi mampu memahami semua soal yang diberikan. Namun berbeda dengan subjek kecerdasan visual rendah, subjek melakukan kesalahan dalam mendefinisikan makna jarak titik ke garis yang disebabkan kesalahan konsep menentukan jarak titik ke garis yang dipahami subjek. Hal ini menunjukkan bahwa kemampuan interpretasi subjek terhadap konsep jarak titik ke garis berbeda.

Hal yang sama juga terjadi pada tahap transformasi. Subjek dengan tingkat kecerdasan visual tinggi tidak melakukan kesalahan transformasi dikarenakan subjek mampu menggambarkan bangun ruang serta dapat mentransformasikan bagian-bagian tersebut dalam dimensi 2. Adapun untuk subjek dengan kecerdasan visual rendah tidak selalu mampu mentransformasikan bagian-bagian bangun ruang ke dalam dimensi 2 yang disebabkan kecerobohan subjek dalam melihat bagian dalam bangun ruang. Hal tersebut menunjukkan bahwa rendahnya kemampuan visual sejalan dengan rendahnya kemampuan seseorang dalam melihat bagian dalam bangun ruang atau dimensi 3. Hal ini sejalan pendapat Campbell Linda, Bruce Campbell, \& Dee Dickinson (2002) yang menyatakan bahwa seseorang dengan kemampuan visual dapat menciptakan gambaran nyata atau visual dari informasi yang diperolehnya.

Pada tahap penyelesaian masalah, subjek dengan kecerdasan visual tinggi mengetahui rumus serta langkah yang digunakan dalam menyelesaikan semua soal yang diberikan. Hanya saja subjek melakukan kecerobohan dalam menyederhanakan bentuk akar. Berbeda dengan subjek dengan kecerdasan visual rendah yang tidak mengetahui rumus yang digunakan untuk menyelesaikan semua soal yang diberikan. Subjek hanya menggunakan rumus yang dihafalnya. Tidak hanya itu, subjek kecerdasan visual rendah juga tidak mengetahui prinsip penggunaan teorema phytagoras dan hanya sekedar menghafal. Samatowa (Sulthon, 2019) mengatakan bahwa pembelajaran sains tidak berkembang secara baik jika hanya mengandalkan hafalan. Oleh sebab itu diperlukannya penekanan 
Newman's Error Analysis Dalam Geometri Ruang Ditinjau Dari Kecerdasan Visual Siswa SMA, Ardina Fahriyanti

penanaman konsep matematika saat pembelajaran di kelas sehingga siswa tidak hanya menghafal, tetapi memahami konsep yang sedang dipelajari.

Pada tahap terakhir yaitu tahap penulisan kesimpulan. Subjek dengan kecerdasan visual tinggi salah dalam menentukan hasil akhir suatu soal yang dikarenakan kesalahan subjek pada tahap sebelumnya. Ketidakmampuan subjek dalam menyelesaikan masalah mengakibatkan subjek tidak mampu menuliskan dengan benar hasil akhir untuk semua soal yang diberikan. Berdasarkan hal ini, maka dapat ditarik kesimpulan bahwa kesalahan pada tahap sebelumnya akan mempengaruhi kesalahan pada tahap selanjutnya untuk tingkat kecerdasan visual manapun. Hal ini berbeda dengan penelitian Mulyadi dkk (2015) yang menghasilkan fakta bahwa subjek dengan kecerdasan visual tinggi hanya melakukan kesalahan pada tahap transformasi dan kesimpulan. Hal ini berarti kesalahan subjek pada tahap transformasi tidak mempengaruhi untuk melakukan kesalahan pada tahap selanjutnya yaitu penyelesaian masalah.

Hasil penelitian ini sejalan dengan Newman (White, 2010) yang mengatakan bahwa jika seseorang mengerjakan soal matematika, maka orang tersebut melewati 5 tahap yaitu tahap membaca soal, tahap memahami soal, tahap transformasi, tahap proses penyelesaian, dan tahap penulisan kesimpulan. Hal ini tampak pada hasil analisis tes dan wawancara yang telah diuraikan sebelumnya, dimana dalam menyelesaikan semua soal yang diberikan, masing-masing subjek melewati 5 tahapan tersebut.

Selain itu, kesalahan yang disebabkan oleh faktor kecerobohan tidak terjadi untuk semua soal. Kesalahan yang diakibatkan karena kesalahan konsep, seperti salah konsep dalam memahami jarak titik ke garis serta salah konsep terorema phytagoras yang dialami subjek kecerdasan visual rendah mengakibatkan subjek melakukan kesalahan untuk semua soal yang diberikan.

Terdapat temuan menarik pada penelitian ini yaitu bagaimana subjek dengan kecerdasan visual tinggi mentransformasikan hal yang ditanyakan ke dalam bentuk 2 dimensi. Subjek menggunakan prinsip dengan menghubungkan unsur-unsur yang ditanyakan dalam soal. Contohnya untuk soal nomor 1, ditanyakan jarak titik E ke garis BD, sehingga subjek menggambarkan segitiga BDE dimana dalam segitiga tersebut memuat unsur yang ditanyakan yaitu titik $\mathrm{E}$ dan garis BD.

\section{KESIMPULAN}

Dalam penelitian ini terdapat dua subjek dengan tingkatan kecerdasan visual yang berbeda, yaitu kecerdasan visual tinggi (VT) dan kecerdasan visual rendah (VR). Masing-masing subjek melakukan lima tahapan dalam NEA yaitu membaca soal, memahami soal, transformasi, proses penyelesaian, serta penulisan kesimpulan. Adanya perbedaan tingkat kecerdasan masing-masing subjek mengakibatkan bervariasinya kesalahan yang dilakukan dalam mengerjakan soal geometri ruang. Berikut merupakan perbedaan letak serta faktor penyebab kesalahan berdasarkan tingkat kecerdasan visual masing-masing subjek. Subjek dengan kecerdasan visual tinggi melakukan kesalahan pada tahap penyelesaian masalah karena kecerobohan serta salah pada tahap penulisan kesimpulan yang 
diakibatkan kesalahan yang dilakukan subjek pada tahap sebelumnya, sedangkan untuk subjek dengan kecerdasan visual rendah melakukan kesalahan pada 4 tahapan NEA, yaitu pada tahap memahami masalah yang diakibatkan salah dalam memahami konsep jarak titik ke garis, tahap transformasi yang disebabkan oleh kecerobohan subjek dalam melihat unsur bangun ruang, tahap penyelesaian soal karena ketidakmampuan dalam prinsip teorema phytagoras, serta pada tahap penulisan kesimpulan yang diakibatkan oleh kesalahan subjek pada tahap sebelumnya.

Berdasarkan hal tersebut dapat disimpulkan bahwa: (1) perbedaan tingkat kecerdasan visual tidak mempengaruhi kemampuan subjek pada tahap membaca soal, (2) tingkat kecerdasan visual yang berbeda berdampak pada pemahaman akan konsep jarak titik ke garis, (3) tingkat kecerdasan visual berdampak pada kemampuan subjek untuk mentransformasikan soal yang diberikan, (4) kesalahan subjek pada tahap sebelumnya akan mempengaruhi kesalahan pada tahap selanjutnya; (5) perbedaan kecerdasan visual kedua subjek tidak mempengaruhi kemampuan komputasi masing-masing subjek.

\section{Saran}

Kesalahan yang dilakukan masing-masing subjek bervariasi bergantung pada kemampuan dalam melihat unsur dalam ruang serta pemahaman konsep yang dimiliki, sehingga disarankan bagi guru untuk mengefektifkan waktu pembelajaran dengan tidak membahas proses komputasi, melainkan dengan menekankan pada pemahaman konsep siswa mengenai cara menentukan jarak titik terhadap suatu garis. Selanjutnya guru dapat menunjukkan berbagai prinsip penyelesaian masalah yang dapat digunakan serta memberikan kesempatan kepada siswa untuk mengidentifikasi langkah yang bisa digunakan dengan memberikan pemilihan langkah tersebut. Selain itu, penting juga menggali pemahaman konsep teorema phytagoras yang dimiliki siswa sebelum mengajarkan materi jarak pada dimensi 3. Dalam tahap transformasi guru dapat memberikan gambaran menggenai bangun ruang dalam dimensi 2 , misalnya melalui media geogebra.

\section{DAFTAR PUSTAKA}

Campbell Linda, Bruce Campbell, dan D. D. (2002). Metode baru Melesatkan Kecerdasan. Depok: Inisasi Press.

Farida, N. (2015). Analisis Kesalahan Siswa SMP Kelas VIII dalam Menyelesaikan Masalah Soal Cerita Matematika. Jurnal Pendidikan Matematika FKIP Univ. Muhammadiyah Metro, 4(2), 4252.

Gardner, H. (2003). Multiple Intelligences. Batam: Interaksara.

Isran. (2017). Analisis Kesalahan Siswa dalam Menyelesaikan Tes Kemampuan Berpikir Kritis Materi

Fungsi Eksponen dengan Panduan Kriteria Watson. Kontinu: Jurnal Penelitian Didaktik Matematika, 1(1), 30-37.

Kementerian Pendidikan dan Kebudayaan. Peraturan Menteri Pendidikan dan Kebudayaan Nomor 24

Tahun 2016 Lampiran 16 Tentang Kompetensi Inti dan Kompetensi Dasar SMA/MA/SMK (2016). 
Newman's Error Analysis Dalam Geometri Ruang Ditinjau Dari Kecerdasan Visual Siswa SMA, Ardina Fahriyanti

Mulyadi, Riyadi, \& S. S. (2015). Cerita Pada Materi Luas Permukaan Bangun Ruang Berdasarkan Newman's Error Analysis (NEA) Ditinjau Dari Kemampuan Spasial. Jurnal Elektronik Pembelajaran Matematika, 3(4), 370-382.

Pateda, M. (1989). Analisis Kesalahan. Flores: Nusa Indah.

Puspendik. (n.d.). Daya Serap Indikator Materi Geometri dan Trigonometri UN SMA IPA Tahun Pelajaran 2017/2018. Retrieved from http://puspendik.kemdikbud.go.id/hasil-un/

Prakitipong, N., \& Nakamura, S. (2006). Analysis of Mathematics Performance of Grade Five Students in Thailand Using Newman Procedure. Journal of International Cooperation in Education, 9(1), $111-122$.

Prihatnani, E. (2016). Prestasi Belajar Matematika Siswa Sman Kabupaten Kulon Progo Dalam Pembelajaran Menggunakan Model Tgt Berbantuan Alat Peraga Ditinjau Dari Kecerdasan Spasial. Scholaria : Jurnal Pendidikan Dan Kebudayaan, 6(2), 29-45.

Singh, P., Abdul, A., \& Sian, T. (2010). The Newman Procedure for Analyzing Primary Four Pupils Errors on Written Mathematical Tasks: A Malaysian Perspective. International Conference on Mathematics Education Research 2010 (ICMER 2010), 8(5), 264-271.

Sulthon. (2019). Pengembangan Media Pembelajaran Sains Berbasis Pemanfaatan Barang-barang Bekas dari Lingkungan Sekitar bagi Siswa Madrasah Ibtidaiyah (MI) di Daerah Pinggiran Kota Kabupaten Kudus. Jurnal Keilmuan Dan Kependidikan Dasar, 11(01), 17-26.

Yaumi, M. (2012). Pembelajaran Berbasis Multiple Intelligences. Jakarta: Dian Rakyat.

White, A. L. (2010). Numeracy, Literacy and Newman's Error Analysis. Journal of Science and Mathematics Education in Southeast Asia, 33(2), 129-148. 